p. 80

\section{現代レクリエイーションの方（その 2)}

一仕索とレクリエーションの理解一 大阪工業大学 西 山 勝 次

レクリエーションが生活の中で，理解されている度 合，その示す方向について前回は施設の利用の側からみ たが，今回は利用する側，実施者の側からのものについ て, 企業別, 年令別, 性別, 地域別等の目的的制限をな くしてアンケードした.この点について, 特に重要な30 才台の回収が少なかつたことについては，考劣なければ ならないことであるが，次回の訓として，今回はこれを もつてサンプルとする，調査内容は1. 現在実施してい るレクリエーションの種目 (㟟択の好みの傾向).

2. 生活の中でどのような位置を占めるか

3.レクリエーションの意義づけ

の3 項目について調查した。

胡查资料 男子136名，女子 29 名（女子は回收数が 少ないので参考とする)

调查方法 質問紙法

1 の調査絬果については自由に記入してもらつたとこ ろ相対パーセントでハイキンクー $35.2 \%$. 旅行一 41.9 \%。遊戯場での遊び（パチンュ，麻街，玉突，ボーリン グ) $-56.6 \%$ ．海水浴一29.4\%。 スポーッー50.0\%。の 五種が上位を占めていた．都会居住者のレクリエーショ ン種目の好みがわかつた。この傾向を満 36 才以下のグ ループと 37 才以上のグループについて対比してみると, 尘理的な身体条件，職業上の地位，家族構成の条件儿よ つても傾问がある。

2 につてみると19項目のらち仕事との関連した質 問10項，交際上にレクリエーションを利用することに 関連したもの3 項, レクリエーションの目的について 6 項の質問に対して，諾当事項を自由に選んですらい，い くつでもよいとして項目別に問題を並べずに，整理の際 に項目別の答を出した。レクリエーション実施の目的に ついては，仕事がよくできるようにするためと考えてい

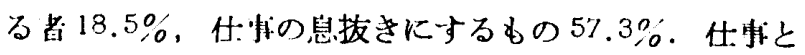
の関連性なく牛活をたのしむもの37\%であつた。これ を総括してみると『レクリエーションは生活の中にあ る. 什事の息拔きのために楽しいものを行い，心をなこ やかにしたり友人や隣人との交際にも利用する』とな
る.すなわち仕事よりの開放と同時に楽しいことを行う ことは人生の中に占める位㯰は大きい。

3 Кついては，仕事との関連的な質問 3 項，人間性に 立つもの 3 項, 健康上の対策とするかどらか 2 項, 勝負 に関して，または睹の対象と考えるかどうか 4 項，につ いて賀問によつて傾向をみることにした。すともとレク リエーションの定義つけとか，意義づけについては，学 校の教有は大きな力となつて働きかけているので，学校 教育の力によつてこの答が出ているのではないかと考え られないこともないが136名の中で相対パーヒントで39 \%あることは傾向があるものと考えてよいであろう，仕 事の能率とレクリエーションが，ひつかかる問と，全然 無関係である立場の問に対して, 満 37 才以上のクルー プがレクリエーションは楽しいからする万がはんの少し 約 36 才以下クループに比へて多いと云うことは，学校 教育の知識が根底にあつたと考えられる。

レクリエーションの実施の計画については従来の私の 調査では，やりたくてもできないと云ら答が多く，とく に大学卒業生でる昭和 35 年頃ではこの答であつた．今 回出来ない理由のらち，眼と金銭的なものとでは，どち らであるかとみると，金銭的理由の方が多いことがわか つたが，社会の経济的な影響は非常に敏感嫁家や個人 のレクリエーションにも影隌する.

女性については若干の回収をみたので丟考までにみる と，男子の満 36 才以下グループと同一傾向を持つ. し かし現在行っているレクリエーションの上位五種目の中 に手芸か入つていることは調查の整理をしていてホット した.

満 36 才以下と満 37 才以上の グルーブ別をした根执 は，「図説日本人の国民性，林知已夫，西平重喜，鈴木 達三著」の道徳心の新古についての考方方か，一つの線 があるとみとめたので, レクリエーションについても考 え方に相異があるか，どおがついてポイントをおいた ためである．仕事とレクリエーションの理解について は，最も新しい教育制度による効果が指向するものと考 えられる。

ただし，この調查のもつとも必要な「人間性」の閏題 の理解度は次の問題とする。 